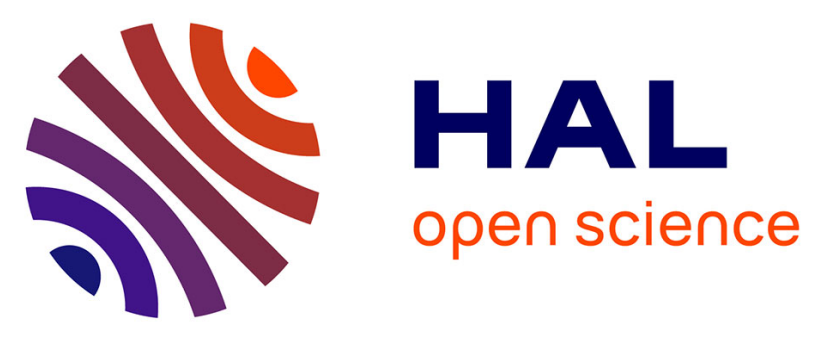

\title{
Physicochemical properties of some hydrophobic room-temperature ionic liquids applied to volatile organic compounds biodegradation processes
}

Alfredo Santiago Rodriguez Castillo, Solène Guihéneuf, Pierre-Francois Biard, Ludovic Paquin, Abdeltif Amrane, Annabelle Couvert

\section{To cite this version:}

Alfredo Santiago Rodriguez Castillo, Solène Guihéneuf, Pierre-Francois Biard, Ludovic Paquin, Abdeltif Amrane, et al.. Physicochemical properties of some hydrophobic room-temperature ionic liquids applied to volatile organic compounds biodegradation processes. Journal of Chemical Technology and Biotechnology, 2018, 93 (1), pp.215-223. 10.1002/jctb.5343 . hal-01685689

HAL Id: hal-01685689

https://hal-univ-rennes1.archives-ouvertes.fr/hal-01685689

Submitted on 31 Jan 2018

HAL is a multi-disciplinary open access archive for the deposit and dissemination of scientific research documents, whether they are published or not. The documents may come from teaching and research institutions in France or abroad, or from public or private research centers.
L'archive ouverte pluridisciplinaire HAL, est destinée au dépôt et à la diffusion de documents scientifiques de niveau recherche, publiés ou non, émanant des établissements d'enseignement et de recherche français ou étrangers, des laboratoires publics ou privés. 


\title{
Physicochemical properties of some hydrophobic room-temperature
}

\section{ionic liquids applied to volatile organic compounds biodegradation}

\section{processes}

\author{
Alfredo Santiago Rodriguez Castillo ${ }^{1}$, Solène Guihéneuf ${ }^{2}$, Pierre-François Biard ${ }^{1 *}$, Ludovic \\ Paquin $^{2}$, Abdeltif Amrane ${ }^{1}$, Annabelle Couvert ${ }^{1}$
}

\begin{abstract}
${ }^{1}$ Ecole Nationale Supérieure de Chimie de Rennes, CNRS, UMR 6226, 11 Allée de Beaulieu, CS 50837, 35708 Rennes Cedex 7, France.
\end{abstract}

${ }^{2}$ Université de Rennes 1, Sciences Chimiques de Rennes, UMR CNRS 6226, Groupe Ingénierie Chimique \& Molécules pour le Vivant (ICMV), Bât. 10A, Campus de Beaulieu, Avenue du Général Leclerc, CS 74205, 35042 Rennes Cedex, France.

*Corresponding author. E-mail: pierre-francois.biard@ensc-rennes.fr. Phone: + 33223238149

\begin{abstract}
BACKGROUND: Ionic liquids (IL) are an interesting solvent choice for specific industrial applications since physicochemical properties can be fine-tuned by modifying the substituent groups or the cation/anion pair. Hydrophobic IL are considered as green solvents and known to be good absorbents for hydrophobic organic compounds. Given their physicochemical properties
\end{abstract}


an industrial application of such compounds can be conceivable. Classical physicochemical properties such as the density, the viscosity and the surface tension have a strong influence on the fluid dynamics, they were therefore measured and determined.

RESULTS: The density, viscosity and surface tension of 23 hydrophobic IL at room temperature were measured. These compounds are potential candidates for the absorption and biodegradation of Volatile Organic Compounds in a two-phase partitioning bioreactor. The thermal expansion coefficient, molecular volume, standard molar entropy and lattice energy were determined for each IL using empirical and semi-empirical equations based on the density values. Viscosity values were correlated by the Arrhenius equation. Then, the surface excess enthalpy and surface excess entropy were determined from the surface tension values.

CONCLUSION: The influence of the presence of different functional moieties (unsaturated bonding, oxygenated and cyanide) and the side chain length in the physicochemical properties of these hydrophobic IL was discussed, since their presence affected directly the density, viscosity and surface tension. 


\section{Introduction}

Ionic liquids (IL) are molten salts composed entirely by a large organic cation associated with a counter ion and usually having a melting point at or below $100{ }^{\circ} \mathrm{C}{ }^{1-3}$. They are generally considered as green solvents, since they have negligible vapor pressure and they are nonflammable, they can often be recycled after being used in a process ${ }^{4,5}$. Given their physicochemical properties (lipophilicity, viscosity, density, etc) and the large number of possible combinations from a structural point of view, ILs are an interesting solvent choice for specific industrial applications ${ }^{2,6}$. A large range of studies has already been carried out in several fields like organic and inorganic synthesis ${ }^{7}$, catalysis ${ }^{8,9}$, new methods for separation ${ }^{10}$, electrometallurgy ${ }^{11}$, metallurgic processes ${ }^{12}$, photochemistry ${ }^{13}$, liquid crystals ${ }^{14}, \mathrm{CO}_{2}$ and gas absorption $^{15}$, enzymatic synthesis ${ }^{9}$, lubricants ${ }^{16}$, materials development, whole-cell applications ${ }^{17,18}$ among others ${ }^{16}$.

Hence, fine-tuning IL physicochemical properties by modifying the substituent groups or the cation/anion pair makes them a really interesting subject of study ${ }^{2,6,19}$. Among all possible IL molecules, hydrophobic ILs are known to be good absorbents for hydrophobic organic compounds ${ }^{6,19}$. They exhibit many advantages for bioreactor applications. In previous works, cytotoxicity and toxicity against activated sludge and zebrafish Danio rerio were assessed ${ }^{20-22}$.

Fluoride release in water and biodegradability were also tested in order to verify possible toxic effects when discharging an hydrophobic IL into the environment or during handling ${ }^{20-22}$. The principle of using ILs to treat VOCs consists to absorb targeted compounds in a non-aqueous phase liquid (NAPL), exhibiting high affinity for pollutants from a gaseous flow. The main purpose of this transfer in a liquid phase is to improve pollutants biodegradation by biological 
material (microorganisms, bacteria, activated sludge ...) contained in an aqueous phase ${ }^{23-25}$ when both phases are mixed in a TPPB (Two-Phase Partitioning Bioreactor). In order to fit the specifications of the NAPL (hydrophobicity, viscosity, toxicity, density ...), and after an exhausting literature research, 23 different ILs were synthesized according to classical conditions, namely involving an alkylation reaction with the appropriate halide and an anion exchange ${ }^{26,27}$. Several cationic scaffolds were explored (imidazoliums, isoquinoliniums, pyrolidinims, morpholiums, triazolium and sulfoniums) including functionalized or non-functionalized alkyl side chains and associated with various anions $\left(\mathrm{PF}_{6}, \mathrm{NTf}_{2}\right.$ and $\left.\mathrm{NfO}\right)$, in order to study the physical-chemical property variations that might be created when the cation alkyl side chain, the core or the anion were modified. The IL synthesized were: [nPrMim] $\left[\mathrm{NTf}_{2}\right],\left[\mathrm{BMim}^{\mathrm{P}}\right]\left[\mathrm{PF}_{6}\right]$, $[\mathrm{BMim}]\left[\mathrm{NTf}_{2}\right]^{28},\left[\mathrm{iPtMim}_{[}\left[\mathrm{PF}_{6}\right],\left[\mathrm{iPtMim}_{[}\right] \mathrm{NTf}_{2}\right],[$ ButenylMim $]\left[\mathrm{PF}_{6}\right]^{29,30},[$ ButenylMim $][\mathrm{NfO}]$, $[$ ButenylMim $]\left[\mathrm{NTf}_{2}\right], \quad[\mathrm{MeOEmim}]\left[\mathrm{NTf}_{2}\right]^{31}, \quad[\mathrm{MeOEMim}][\mathrm{NfO}], \quad[$ EtOEMim $]\left[\mathrm{NTf}_{2}\right]$, $\left[\mathrm{MeOC}_{2} \mathrm{OC}_{2} \mathrm{Emim}\right]\left[\mathrm{NTf}_{2}\right] \stackrel{32,33}{ }, \quad\left[\mathrm{CNC}_{3} \mathrm{Mim}\right]\left[\mathrm{NTf}_{2}\right]{ }^{34}, \quad[\mathrm{OctIq}]\left[\mathrm{NTf}_{2}\right], \quad\left[\mathrm{C}_{10} \mathrm{Iq}_{[\mathrm{NTf}}\right]^{35}$ and $\left.[\mathrm{MeOEIq}]\left[\mathrm{NTf}_{2}\right], \quad\left[\mathrm{EtOEIq}_{[}\right] \mathrm{NTf}_{2}\right], \quad[\mathrm{BMPyrr}]\left[\mathrm{NTf}_{2}\right], \quad\left[\mathrm{MeOEMMorph}_{[}\left[\mathrm{NTf}_{2}\right]\right.$, [EtOEMMorph][NTf 2$],\left[\mathrm{BMTriaz}_{2}\left[\mathrm{NTf}_{2}\right],\left[\mathrm{CF}_{2} \mathrm{CFEBTriaz}_{[}\left[\mathrm{NTf}_{2}\right]^{36},\left[\mathrm{AllylEt}_{2} \mathrm{~S}\right]\left[\mathrm{NTf}_{2}\right]^{37}\right.\right.$.

The density, the viscosity and the surface tension have a strong influence on the fluid dynamics and subsequently on the cell population, pumping cost and mass-transfer ${ }^{38}$. Thus, in order to use one of these ILs in an industrial application, information of the IL physical properties are required. Therefore, this paper reports on the physical properties of ILs selected as good candidates for TPPB degradation of hydrophobic VOCs. Density, viscosity and surface tension were examined. The data were correlated to different thermodynamic models. 


\section{Experimental procedures}

23 ILs were synthesized (Table 1) and their density, viscosity and surface tensions were measured in the range $288.15-318.15 \mathrm{~K}^{22}$. The plots of the temperature variations of these variables are presented as supplementary data.

\section{Density measurements}

IL density versus temperature was measured using an Anton Paar DMA 350 Ex vibrating tube

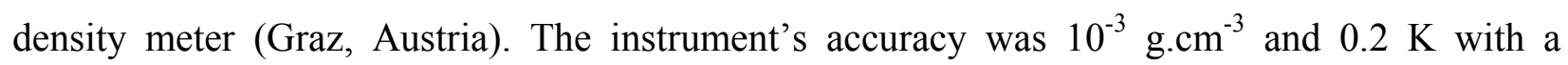
repeatability of $5.10^{-4}{\mathrm{~g} . \mathrm{cm}^{-3}}^{-3}$ and $0.1 \mathrm{~K}$. Density measurements were obtained from two different samples of the same ionic liquid. The first sample was first warmed (maximum at $313.15^{\circ} \mathrm{C}$ ) and pumped in the density meter; the second one was cooled (minimum at $288.15 \mathrm{~K}$ ) and then pumped. Density values were recorded when the temperature varied from $5.0 \mathrm{~K}$ and until each sample was at room temperature. Each sample was analyzed in duplicate. The density meter calibration was performed at atmospheric pressure using methanol (Sigma-Aldrich, $\geq 99.9 \%$ ) and absolute ethanol (TechniSolv ${ }^{\circledR} \geq 99.5 \%$ ) to confirm the accuracy of the density meter.

\section{Viscosity measurements}

IL viscosity was measured using a Brookfield DV-11+ Programmable rheometer at temperatures ranging from 293.15 to $303.15 \mathrm{~K}$ at ambient pressure. The instrument accuracy was $\pm 1 \%$ of the full scale range with a repeatability of $\pm 2 \%$. The hydrophobic IL sample was maintained at the desired temperature for $15 \mathrm{~min}$ to ensure thermal equilibrium of the sample before any measurement. The temperature measurement uncertainty of the instrument was $\pm 0.1 \mathrm{~K}( \pm 0.05 \mathrm{~K}$ 
for the thermostatic bath). All the ILs exhibited a Newtonian behavior. Thus, at each temperature, the shear stress was measured as a function of the shear rate which was gradually increased and then decreased. The viscosity was subsequently deduced from the slope of the linear relationship between the shear stress and the shear rate. Each sample was analyzed in duplicate at each temperature.

\section{Surface tension measurements}

IL surface tension was measured using a Tracker-S tensiometer (Teclis Instruments, France) at temperatures ranging between from $\mathrm{T} 288.15$ to $318.15 \mathrm{~K}$ at ambient pressure using a thermostatic bath (uncertainty of $\pm 0.1 \mathrm{~K}$ ). A liquid pendant drop at the end of a needle was illuminated by a light source and then analyzed by an optical system. Successive drop images were captured by a video camera fitted with a telecentric lens. The boundary of the drop edge was then digitized to produce a series of values for analysis. Needle holding the drop was adjusted to be as vertical as possible in order to make symmetrical drop images, thus only one side was analyzed. A boundary was also set in the software in furtherance of acquiring only usable data which corresponds to the limit of the needle tip. During the measurement, the software generated an initial value for surface tension and drop radius (at top or bottom of the drop) to generate a set of theoretical coordinates for the drop based on the Young-Laplace

equation ${ }^{39}$. Values for every experimental and theoretical coordinate were examined to generate an overall error margin. Then, the initial surface tension and drop radius values were slightly modified and the process was repeated a number of iterations; subsequently, a minimum error between theoretical and experimental values was obtained, and the surface tension and drop radius values yielding this lowest error were reported thereafter. Surface tension values accuracy 
were $\pm 0.005 \mathrm{mN} . \mathrm{m}^{-1}$ and the temperature sensor had an uncertainty of $\pm 0.01 \mathrm{~K}$. Each sample was analyzed in duplicate at each temperature. 


\section{Results and Discussion}

\section{Influence of the temperature on the density: Experimental data}

Experimental densities $(\rho)$ of the studied ILs are summarized in Table 2. For a given temperature, density of ionic liquids with the same anion follows the following order:

$$
[\text { Morph }]>[\text { Triaz }]>[\text { im }]>[\text { S }]>[\text { Pyrr }]>[\text { Iq }]
$$

For ILs with the same cation, the density follows the order:

$$
[\mathrm{NfO}]>\left[\mathrm{NTf}_{2}\right]>\left[\mathrm{PF}_{6}\right]
$$

At $298.15 \mathrm{~K}$, IL densities measured were between $29.1 \%$ and $51.1 \%$ higher compared to water density $\left(997.0 \mathrm{~kg} \mathrm{~m}^{-3}\right)$. Density increased when the side of the alkyl chain size increases. As expected, the addition of an ether group inside the alkyl side chain increased slightly the density ${ }^{40}$ and the addition of several oxygen molecules reduced the density due to interionic hydrogen bonding ${ }^{41-43}$. The presence of an unsaturated bond in the side alkyl chain augmented density of the IL. The addition of a methyl group to the side alkyl chain reduced density; while the addition of a cyanide group increased density.

\section{Density-temperature correlations}

Given the linear behavior of the density variation with the temperature, experimental values were satisfactorily correlated (Eq. 1) by a linear regression with determination coefficients $\mathrm{R}^{2}$ higher than 0.99 and with the temperature in $\mathrm{K}$ (supplementary material Table 1):

$$
\rho / k g \cdot m^{-3}=A+B(T / K)
$$


The measured density data appeared in agreement with the available literature values. Indeed, density of $[\mathrm{Bmim}]\left[\mathrm{NTf}_{2}\right]$ was $1.1 \%$ lower than the value reported by Jin et al. ${ }^{44}$ and in good agreement with those of Chen et al. ${ }^{45}$ and Zhang et al. ${ }^{46}$. For $[\mathrm{Bmim}]\left[\mathrm{PF}_{6}\right]$, densities values were in average 1.1 and $0.4 \%$ higher than those reported by ${ }^{46}$ and Jin et ll $^{44}$. The density measurements of $[\mathrm{BMPyrr}]\left[\mathrm{Ntf}_{2}\right]$ were in average $0.2 \%$ higher and $1.3 \%$ lower than those reported by Chen et al. ${ }^{45}$ and Zhang et al. ${ }^{46}$. The density measurements of [MeOEmim] $\left[\mathrm{NTf}_{2}\right]$ and [EtOEmim] $\left[\mathrm{Ntf}_{2}\right]$ were $0.4 \%$ and $0.6 \%$ lower than those reported by Chen et al. ${ }^{45}$. The different degrees of purity (water and $\mathrm{Cl}^{-}$contents) influence directly the density of an $\mathrm{IL}^{47}$. The water influence is milder than the $\mathrm{Cl}^{-}$influence. Assuming that most water was eliminated by means of the purification procedure previously described (Rodriguez et al., 2016) ${ }^{22}$, the slight differences found between the literature and our results can be explained by different $\mathrm{Cl}^{-}$contents.

The density can also be correlated to the isobaric thermal expansion coefficient $\left(\alpha_{P}\right)$ according to Eq. 2:

$$
\ln \left(\rho / K g \cdot m^{-3}\right)=b-\alpha_{P} \cdot(T / K)
$$

Where $b$ is an empirical constant and $\alpha_{P}$ accounts for the fractional change in density when the temperature increases at constant pressure and is defined by the following expression:

$$
\alpha_{P} / K^{-1}=-\frac{1}{\rho}\left(\frac{d \rho}{d T}\right)_{P}=-\left(\frac{d \ln \rho}{d T}\right)_{P}
$$

The value of the thermal expansion coefficient of $[\mathrm{Bmim}]\left[\mathrm{NTf}_{2}\right]$ was in good agreement with the value reported by Jacquemin et al. (supplementary material Table 2) ${ }^{48}$. Nevertheless for $[\mathrm{Bmim}]\left[\mathrm{PF}_{6}\right]$ the values was $28 \%$ higher ${ }^{48}$. Results were in good agreement with the literature in 
which most of the thermal expansion coefficients are in the range from 5 to $7 \times 10^{-4} \mathrm{~K}^{-1}$ for imidazolium and pyridinium ILs ${ }^{48}$, but also for triazolium, pyrrolidilium and sulfonium ILs. Nevertheless, morpholinium ILs were found to have higher values than the other ILs (around $\left.9 \times 10^{-4} \mathrm{~K}^{-1}\right)$.

\section{Thermodynamic data calculation}

The standard molar entropy $\left(S^{0}\right.$ in $\left.\mathrm{J} \mathrm{K}^{-1} \mathrm{~mol}^{-1}\right)$, the molecular volume $\left(V_{m}\right.$ in $\left.\mathrm{nm}^{3}\right)$ and the lattice energy $\left(U_{P O T}\right.$ in $\left.\mathrm{kJ} \mathrm{mol}^{-1}\right)$ at $298.15 \mathrm{~K}$ can be obtained from the experimental density according to the following equations ${ }^{49,50}$ :

$$
\begin{gathered}
V_{m} / \mathrm{nm}^{3}=10^{27} \cdot M /(N \cdot \rho) \\
S^{0} / \mathrm{J} \cdot \mathrm{K}^{-1} \cdot \mathrm{mol}^{-1}=1246.5 \cdot V_{m}+29.5 \\
U_{\text {РОТ }} / \mathrm{kJ} \cdot \mathrm{mol}^{-1}=\gamma \cdot(\rho / M)^{1 / 3}+\delta
\end{gathered}
$$

Where $M$ is the molar mass $\left(\mathrm{kg} \mathrm{mol}^{-1}\right), \rho$ is the density $\left(\mathrm{kg} \mathrm{m}^{-3}\right), \mathrm{N}$ is the Avogadro's constant $\left(6.0224510^{23} \mathrm{~mol}^{-1}\right), \gamma$ and $\delta$ are constants having values of $19.812 \mathrm{~kJ} \mathrm{~mol}^{-1} \mathrm{~m}$ and $103.8 \mathrm{~kJ} \mathrm{~mol}^{-1}$ respectively.

The molecular volumes of the material were yielded by the experimental density data (supplementary material Table 3). The mean contribution of methylene group $\left(-\mathrm{CH}_{2}-\right)$ to the molecular volume was $0.0276 \mathrm{~nm}^{3}$ for $\left[\mathrm{C}_{\mathrm{n}} \operatorname{mim}\right]\left[\mathrm{NTf}_{2}\right](\mathrm{n}=3,4), 0.0272 \mathrm{~nm}^{3}$ for $\left[\mathrm{C}_{\mathrm{n}} \mathrm{Iq}\right]\left[\mathrm{NTf}_{2}\right]$ $(\mathrm{n}=8,10), 0.0328 \mathrm{~nm}^{3}$ for $\left[\mathrm{C}_{\mathrm{n}} \mathrm{OEmim}\right]\left[\mathrm{NTf}_{2}\right](\mathrm{n}=1,2)$ and $0.0283 \mathrm{~nm}^{3}$ for $\left[\mathrm{C}_{\mathrm{n}} \mathrm{OEMMorph}\right]\left[\mathrm{NTf}_{2}\right]$ $(\mathrm{n}=1,2)$ at $298.15 \mathrm{~K}$. For the families alkylimidazolium, isoquinolinium and morpholinium, these 
values appeared in good agreement with the reported values of $0.0275 \mathrm{~nm}^{3}$ for $\left[\mathrm{C}_{\mathrm{n}} \mathrm{mim}\right]\left[\mathrm{NTf}_{2}{ }^{49}\right.$, $0.0280 \mathrm{~nm}^{3}$ for $\left[\mathrm{C}_{\mathrm{n}} \mathrm{py}\right]\left[\mathrm{NTf}_{2}\right]^{51-53}$ and for n-alcohols ${ }^{54}, 0.0277 \mathrm{~nm}^{3}$ for $\left[\mathrm{C}_{\mathrm{n}} \mathrm{mpy}\right]\left[\mathrm{NTf}_{2}\right]^{55}$ and $0.0279 \mathrm{~nm}^{3}$ for aminoacids ${ }^{56-58}$. The values for ether functionalized imidazoliums were $20 \%$ higher than for alkylimidazoliums.

The mean contribution for other group could be also determined: methyl $\left(-\mathrm{CH}_{3}\right)$ contribution to molecular volume were $0.0277 \mathrm{~nm}^{3}$ for $\left[\mathrm{Bmim}^{2}\left[\mathrm{NTf}_{2}\right] /\left[\mathrm{iPentmim}_{[}\left[\mathrm{NTf}_{2}\right]\right.\right.$ and $0.0288 \mathrm{~nm}^{3}$ $[\mathrm{Bmim}]\left[\mathrm{PF}_{6}\right] /\left[\mathrm{iPentmim}_{[}\right]\left[\mathrm{PF}_{6}\right]$, namely close to those reported in the literature for the contribution of methylene ${ }^{49}$. Double bounds contribution to the molecular volume were -0.0095 $\mathrm{nm}^{3}$ for $[\mathrm{Bmim}]\left[\mathrm{NTf}_{2}\right] /[$ Butenylmim $]\left[\mathrm{NTf}_{2}\right],-0.0093 \mathrm{~nm}^{3}$ for $[$ Bmim $]\left[\mathrm{PF}_{6}\right] /[$ Butenylmim $]\left[\mathrm{PF}_{6}\right]$ and $-0.0116 \mathrm{~nm}^{3}$ for $[\mathrm{Bmim}][\mathrm{NfO}] /[$ Butenylmim $][\mathrm{NfO}]$; cyanide $(-\mathrm{CN})$ contribution to the molecular volume was $0.0277 \mathrm{~nm}^{3}$ for $[\mathrm{nPrmim}]\left[\mathrm{NTf}_{2}\right] /\left[\mathrm{CNC}_{3} \operatorname{mim}\right]\left[\mathrm{NTf}_{2}\right]$.

Entropy contributions per methylene group was $34.4 \mathrm{~J} . \mathrm{K}^{-1}$ for $\left[\mathrm{C}_{\mathrm{n}} \operatorname{mim}\right]\left[\mathrm{NTf}_{2}\right](\mathrm{n}=3,4), 33.8 \mathrm{~J} . \mathrm{K}^{-1}$ for $\left[\mathrm{C}_{n} \mathrm{Iq}\right]\left[\mathrm{NTf}_{2}\right](\mathrm{n}=8,10)$ and $40.9 \mathrm{~J} \cdot \mathrm{K}^{-1}$ for $\left[\mathrm{C}_{\mathrm{n}} \mathrm{OEmim}\right]\left[\mathrm{NTf}_{2}\right](\mathrm{n}=1,2)$ and $35.2 \mathrm{~J}^{\mathrm{K}} \mathrm{K}^{-1}$ for $\left[\mathrm{C}_{\mathrm{n}} \mathrm{OEMMorph}\right]\left[\mathrm{NTf}_{2}\right](\mathrm{n}=1,2)$ at $298.15 \mathrm{~K}$. These values were in good agreement with the

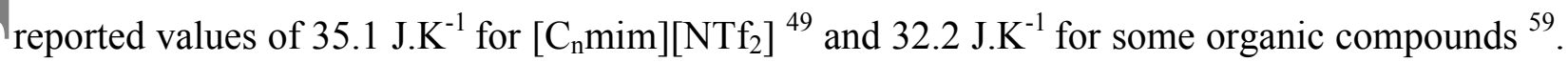
Moreover, the mean contribution of methyl $\left(-\mathrm{CH}_{3}\right)$ to entropy was $34.5 \mathrm{~J} . \mathrm{K}^{-1}$ for

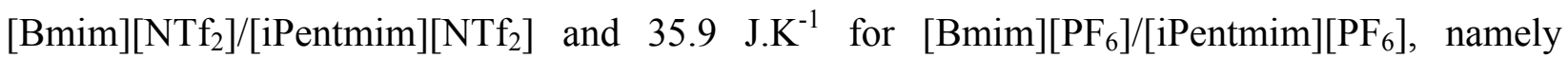
similar values to those reported for the contribution of methylene ${ }^{49}$; double bounds contribution

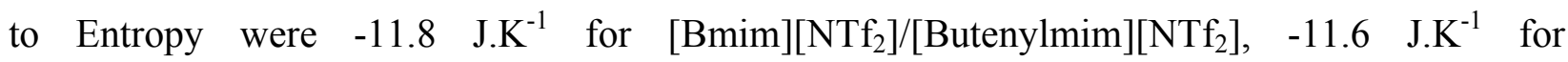
$[\mathrm{Bmim}]\left[\mathrm{PF}_{6}\right] /[$ Butenylmim $]\left[\mathrm{PF}_{6}\right]$ and $-14.5 \mathrm{~J} \cdot \mathrm{K}^{-1}$ for $[\mathrm{Bmim}][\mathrm{NfO}] /[$ Butenylmim $][\mathrm{NfO}]$; cyanide $(-\mathrm{CN})$ contribution to entropy is $19.4 \mathrm{~J} . \mathrm{K}^{-1}$ for $[\mathrm{nPrmim}]\left[\mathrm{NTf}_{2}\right] /\left[\mathrm{CNC}_{3} \mathrm{mim}\right]\left[\mathrm{NTf}_{2}\right]$. 


\section{Influence of the temperature on the viscosity}

Viscosity values ranged from $58.7 \mathrm{mPa}$ s to $667.0 \mathrm{mPa} \mathrm{s}$ at $20^{\circ} \mathrm{C}$ (Table 3). It highlights that industrial applications might be hindered for some ILs by these high viscosities which affect the pumping cost and the mass-transfer and dynamics performances. The viscosity values of $[\mathrm{Bmim}]\left[\mathrm{NTf}_{2}\right]$ were in average $2.6 \%$ and $7.7 \%$ lower than those reported by Jin et al. ${ }^{44}$ and Chen et al. ${ }^{45}$ respectively, $6.0 \%$ higher than those reported by $\mathrm{Yu}$ et al. ${ }^{46}$ and in close agreement with those of Jason et al. ${ }^{60}$. The viscosity values of $[\mathrm{Bmim}]\left[\mathrm{PF}_{6}\right]$ were in average $13.9 \%$ lower than those reported by $\mathrm{Yu}$ et al. ${ }^{46}, 6.9 \%$ higher than those reported by Jin et al. ${ }^{44}$ and in agreement with those of Jason et al. ${ }^{60}$. The viscosity measurements of [BMPyrr] $\left[\mathrm{NTf}_{2}\right]$ were in average $2.7 \%$ and $10.5 \%$ higher than those reported by Chen et al. ${ }^{45}$ and $\mathrm{Yu}$ et al. ${ }^{46}$ respectively and 7.0 $\%$ lower than those reported by Jin et al. ${ }^{44}$. The viscosity measurements of [MeOEmim] $\left.\mathrm{NTf}_{2}\right]$ and $\left[\right.$ EtOEmim] $\left[\mathrm{NTf}_{2}\right]$ were $6.9 \%$ higher and $14.2 \%$ lower than those reported by Chen et al. ${ }^{45}$.The differences in viscosity values can be attributed to a diverse range of impurities of the samples, the water content, especially the $\mathrm{Cl}^{-}$content and the method of determination reported in literature ${ }^{46,47,61-64}$.

The temperature dependence of the viscosity for non-associated electrolytes can be satisfactorily described by the Arrhenius equation (Eq. 8).

$$
\ln (\mu / \mathrm{mPa} \cdot \mathrm{s})=\ln \mu_{\infty}+\frac{E_{\mu}}{R T}
$$

Where $E_{\mu}$ represents the activation energy for viscous flow, giving an estimation of the energy level needed by the anions and cations to move freely inside the IL; $\mu_{\infty}$ represents the 
viscosity at infinite temperature and is an indicator of the extent of the effect from the constitutive anion-cation structure on the IL viscosity.

The Arrhenius equation provided a correct estimation of the viscosity of all ILs tested (supplementary material Table 4). The viscosity and the activation energy of ILs with the same anion followed the order for a given temperature:

$$
[\text { Morph }]>[\text { Iq }]>[\text { Triaz }]>[\text { Pyrr }]>[\text { im }]>[S]
$$

For ILs with the same cation, the viscosity and the activation energy were as follows, in agreement with the related literature ${ }^{65-68}$ :

$$
[\mathrm{NfO}]>\left[\mathrm{PF}_{6}\right]>\left[\mathrm{NTf}_{2}\right]
$$

Concerning the alkyl chain, the obtained results confirmed that the longer the chain, the higher the viscosity and the activation energy. As expected, when replacing a methylene inside the alkyl chain by an ether molecule increases the viscosity and the activation energy (e.g. $\left.[\mathrm{MeOEmim}]\left[\mathrm{NTf}_{2}\right]>[\mathrm{Bmim}]\left[\mathrm{NTf}_{2}\right]\right)^{43}$. The viscosity and the activation energy were higher for the ILs with the same anion and cation core when the alkyl chain has the form $-\mathrm{ROCH}_{3}$ than the form $-\mathrm{ROC}_{2} \mathrm{H}_{7}$. Also, the addition of several oxygen ether group reduced the viscosity and the activation energy because an alkyl ether side chain reduces the viscosity of the IL, which results from the alkoxy chain rotational flexibility (which increases the conformational degrees of freedom) that eases mass transport, but also benefits to the polarity that tends to boost the dipoledipole interactions inside the molecule (generally reducing the viscosity). Consequently, this behavior suggests that the flexibility of the ether side chain is more important than its polarity 41,42,45,69-72. Moreover, the presence of an unsaturated bond in the side alkyl chain may have an 
impact on the viscosity of the IL according to the anion inside the molecule. For $\left[\mathrm{PF}_{6}\right]$ ionic liquids, the viscosity and the activation energy were lower than the identical saturated alkyl side chain, but for $\left[\mathrm{NTf}_{2}\right]$ and $[\mathrm{NfO}]$ anions, the values were higher. This can be attributed to the fact that the freedom degrees of configuration of the $\left[\mathrm{NTf}_{2}\right]$ and $[\mathrm{NfO}]$ anions are higher than that of the $\left[\mathrm{PF}_{6}\right]$ anion, reducing the coulombic forces and hence improved the charges distribution $42,69,71,73$.

\section{Influence of the temperature on the surface tension}

Surface tensions $(\sigma)$ of the studied ionic liquids were lower than water surface tension with values in the range $21.58-41.51 \mathrm{mN} \mathrm{m}^{-1}$ at $298.15 \mathrm{~K}$ (Table 4). The measured surface tensions of $[\mathrm{Bmim}]\left[\mathrm{NTf}_{2}\right]$ were in average 1.5\% lower than those reported by Huddleston et al ${ }^{74}$ and $0.5 \%$ higher than those reported by Kolbeck et al. ${ }^{75}$. The measured surface tensions of $\left[\mathrm{Bmim}^{\mathrm{B}}\right]\left[\mathrm{PF}_{6}\right]$ were in average $1.5 \%$ lower than those reported by Huddleston et al. ${ }^{74}$ and Kilaru et al. ${ }^{76}$. The measured surface tensions of $[\mathrm{BMPyrr}]\left[\mathrm{NTf}_{2}\right]$ was in close agreement with Kolbeck et al. ${ }^{75}$. Values measured for the different ILs were, in some cases, smaller than in literature. Deviations superior than $10 \%$ most often occur when surface tension is measured by the Du Noüy ring and the capillary rise methods which might suggest systematic discrepancies depending on the investigational technique ${ }^{77}$. The pendant drop method (compared to the ring method) is based on strict working equations; where no calibration procedure or corrections are needed (surface tension measured of ultrapure water was $72.0 \mathrm{mN} \cdot \mathrm{m}^{-1}{ }^{78}$ ). However, surface tension measurements could be affected by the additional impurities contained in the ILs, e.g., different water content, halides rates or alkali metal from the metathesis.

Surface tension of ILs with the same anion followed the order for a given temperature: 


$$
[\text { Pyrr }]>[\mathrm{im}]>[\text { Triaz }]>[\text { Morph }]>[\text { Iq }]
$$

For ILs with the same cation, the surface tension followed the order for a given temperature:

$$
\left[\mathrm{PF}_{6}\right]>\left[\mathrm{NTf}_{2}\right]>[\mathrm{NfO}]
$$

The surface tension decreased when the side of the alkyl chain size increases. The addition of an ether group inside the alkyl side chain increased considerably the surface tension (e.g. $\left.[\mathrm{MeOEmim}]\left[\mathrm{NTf}_{2}\right]>[\mathrm{Bmim}]\left[\mathrm{NTf}_{2}\right]\right)$. Nevertheless the position of the oxygen molecule at the side alkyl chain seemed to have a higher influence on the surface tension because even if an oxygen molecule increases the conformational degrees of freedom of an IL, a longer aliphatic side chain next to the oxygen reduces the dipole-dipole interactions that might be created inside the molecules; increasing therefore cation rigidity leading to a slight reduction of surface tension (e.g. $[\mathrm{MeOEmim}]\left[\mathrm{NTf}_{2}\right]>[$ EtOEmim $]\left[\mathrm{NTf}_{2}\right]$ and $[\mathrm{MeOEIq}]\left[\mathrm{NTf}_{2}\right]>[$ EtOEIq $\left.]\left[\mathrm{NTf}_{2}\right]\right)$. However, the addition of several oxygen molecules increased interionic hydrogen bonding ${ }^{41-43}$, and hence an increase of the surface tension was expected. Nevertheless results showed that the surface tension was more related to the aliphatic side chain next to the oxygen than the presence of several oxygen molecules in the side alkyl chain of the IL $\left([\mathrm{MeOEOEmim}]\left[\mathrm{NTf}_{2}\right] \approx\right.$

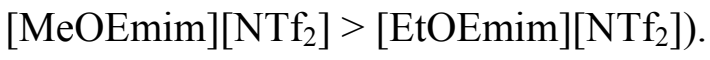

The presence of an unsaturated bond in the side alkyl chain had different effects on the surface tension and depended on the counter-ion. For $\left[\mathrm{NTf}_{2}\right]$ and $[\mathrm{NfO}]$, surface tension increased (e.g. $[$ Butenylmim $]\left[\mathrm{NTf}_{2}\right]>[\mathrm{Bmim}]\left[\mathrm{NTf}_{2}\right]$ and . [Butenylmim $\left.][\mathrm{NfO}]>[\mathrm{Bmim}][\mathrm{NfO}]\right)$, but in presence of $\left[\mathrm{PF}_{6}\right]$ it decreased (e.g. $[\mathrm{Bmim}]\left[\mathrm{PF}_{6}\right]>[$ Butenylmim $]\left[\mathrm{PF}_{6}\right]$ ). The addition of a methyl or a cyanide group to the side alkyl chain increased surface tension. 
The surface tension $(\sigma)$ represents the free energy of a minimum surface area $\left(G^{S}\right)$ at a boundary layer that separates liquid and vapor faces ${ }^{79-81}$. The surface excess enthalpy $\left(H^{S}\right)$ and surface excess entropy $\left(S^{S}\right)$ were calculated based on the measured surface tensions at atmospheric pressure. Eqs 9 to 10 present the surface thermodynamic functions that were derived from the temperature dependence of the surface of a homogeneous liquid ${ }^{76,82}$ :

$$
\begin{gathered}
G^{S} / \mathrm{mN} \cdot \mathrm{m}^{-1}=H^{S}-T \cdot S^{S} \\
S^{S} / \mathrm{mN} \cdot \mathrm{m}^{-1} \cdot \mathrm{K}^{-1}=-\left(\frac{\partial \sigma}{\partial T}\right)_{P}
\end{gathered}
$$

Where $G^{s}$ is the Gibbs energy related to the surface tension of a homogeneous liquid. Values of surface excess entropies are in good agreement with values founds in literature ${ }^{76}$ and compared to the values of organic compounds such as ethanol, benzene or pyridine with $0.086 \mathrm{mN} \mathrm{m}^{-1} \mathrm{~K}^{-1}$, $0.13 \mathrm{mN} \mathrm{m}^{-1} \mathrm{~K}^{-1}$ and $0.1369 \mathrm{mN} \mathrm{m}^{-1} \mathrm{~K}^{-1}$ respectively ${ }^{83}$ (supplementary material Table 5). Most of ILs have lower surface excess entropies which imply a higher level of organization of the ionic liquids structure.

According to the results presented in supplementary material Table 5, similarly to surface tension, surface excess entropy of an IL depends on both the anion and the cation of the IL. From the literature, energetic interactions determine the surface tension, as the size of the anion, the cation and the length of the side alkyl chain ${ }^{84,85}$. A big counter-ion allows a more delocalized charge, inducing a decrease on the ability to hydrogen bonding ${ }^{80}$. Nevertheless, results show that increasing the anion size was not directly associated with a reduction in the surface tension; an increment on the length of the alkyl side chain produces a reduction of the surface tension. The 
increase in size of the molecules leads to the dispersion of the ion charge, thus increasing the Van der Waals forces ${ }^{84}$ and reducing the hydrogen bond strength inside the IL.

\section{Conclusion and outlooks}

The present work assessed the density, viscosity and surface tension of 23 hydrophobic ILs that might be selected as good candidates for absorption and TPPB degradation of hydrophobic VOCs. The data were well correlated to different polynomial equations or thermodynamic models. The thermal expansion coefficient, molecular volume, standard molar entropy, lattice energy, activation energy for viscous flow, surface excess enthalpy and surface excess entropy were determined for all studied ILs. Values are in good agreement with those presented in the literature.

The density and viscosity increased when the side of the alkyl chain size increased. The addition of an ether group inside the alkyl side chain increased slightly the density and reduced the viscosity; however the addition of several oxygen molecules reduced both the density and the viscosity. The presence of an unsaturated bond in the side alkyl chain augmented the density of the IL and had an impact on the viscosity of the IL according to the counter-anion inside the molecule. The addition of a methyl group to the side alkyl chain reduced density; while the addition of a cyanide group increased density.

The surface tension decreased when the side of the alkyl chain size increased. The addition of an ether group inside the alkyl side chain increased considerably the surface tension. The presence of an unsaturated bond in the side alkyl chain had different effects on the surface tension and depended on the counter-ion. The addition of a methyl or a cyanide group to the side alkyl chain increased surface tension. 
Effect on density, viscosity and surface tension when modifying the alkyl side chain, cation and anion could be therefore correlated.

\section{Acknowledgements}

The authors want to thank the ANR for the funding support (Project ANR 12 BLAN 007

01) 


\section{References}

1. Wilkes, J. S. A short history of ionic liquids-from molten salts to neoteric solvents. Green Chem. 4, 73-80 (2002).

2. Wilkes, J. S., Levisky, J. A., Wilson, R. A. \& Hussey, C. L. Dialkylimidazolium chloroaluminate melts: a new class of room-temperature ionic liquids for electrochemistry, spectroscopy and synthesis. Inorg. Chem. 237, 1263-1264 (1982).

3. Welton, T. Room-temperature ionic liquids: solvents for synthesis and catalysis. 2. Chem. Rev. 99, 2071-2083 (1999).

4. Earle, M. J. \& Seddon, K. R. Ionic liquids. Green solvents for the future. Pure Appl. Chem. 72, 1391-1398 (2000).

5. Huddleston, J. G., Willauer, H. D., Swatloski, R. P., Visser, A. E. \& Rogers, R. D. Room temperature ionic liquids as novel media for ' clean' liquid - liquid extraction. Chem. Commun. (Camb). 1765-1766 (1998).

6. Milota, M., Mosher, P. \& Li, K. RTIL absorption of organic emissions from press and dry exhaust. For. Prod. J. 58, 97-101 (2008).

7. Ben Ghanem, O. et al. Studies on the Physicochemical Properties of Ionic Liquids Based On 1-Octyl-3-methylimidazolium Amino Acids. J. Chem. Eng. Data 60, 1756-1763 (2015).

8. Özdemir, İ., Demir, S., Gök, Y., Çetinkaya, E. \& Çetinkaya, B. Synthesis of novel palladium-carbene complexes as efficient catalysts for amination of aryl chlorides in ionic liquid. J. Mol. Catal. A Chem. 222, 97-102 (2004).

9. Sheldon, R. A. Catalytic reactions in ionic liquids. Chem. Commun. (Camb). 2399-2407 
(2001). doi:10.1039/b107270f

10. Visser, A. E., Swatloski, R. P. \& Rogers, R. D. pH-Dependent partitioning in room temperature ionic liquids. Green Chem. 2, 1-4 (2000).

11. Quinn, B. M., Ding, Z., Moulton, R. \& Bard, A. J. Novel electrochemical studies of ionic liquids. Langmuir 18, 1734-1742 (2002).

12. Endres, F. Ionic Liquids: Solvents for the Electrodeposition of Metals and Semiconductors. ChemPhysChem 3, 144-154 (2002).

13. Gordon, C. M. \& McLean, A. J. Photoelectron transfer from excited-state ruthenium(ii) tris(bipyridyl) to methylviologen in an ionic liquid. Chem. Commun. 1395-1396 (2000). doi:10.1039/b003754k

14. Gordon, C. M. C., Holbrey, J. D. J., Kennedy, A. R. A. \& Seddon, K. R. K. Ionic liquid crystals: hexafluorophosphate salts. J. Mater. Chem. 8, 2627-2636 (1998).

15. Bates, E. D., Mayton, R. D., Ntai, I., Davis Jr., J. H. \& Davis, J. H. CO(2) capture by a task-specific ionic liquid. J. Am. Chem. Soc. 124, 926-7 (2002).

16. Ye, C., Liu, W., Chen, Y. \& Yu, L. Room-temperature ionic liquids: a novel versatile lubricant. Chem. Commun. 2244-2245 (2001).

17. Romero, A. et al. Toxicity and biodegradability of imidazolium ionic liquids. J. Hazard. Mater. 151, 268-73 (2008).

18. Cull, S. G., Holbrey, J. D., Vargas-Mora, V., Seddon, K. R. \& Lye, G. J. RoomTemperature Ionic Liquids as Multiphase Bioprocess Operations. Biotechnol. Bioeng. 69, $227-233(2000)$.

19. Milota, M., Mosher, P. \& Li, K. VOC and HAP removal from dryer exhaust gas by 
absorption into ionic liquids. For. Prod. J. 57, $73-77$ (2007).

20. Darracq, G. et al. Activated Sludge Acclimation for Hydrophobic VOC Removal in a Two-Phase Partitioning Reactor. Water, Air, Soil Pollut. 223, 3117-3124 (2012).

21. Dumont, E. et al. Hydrophobic VOC absorption in two-phase partitioning bioreactors; influence of silicone oil volume fraction on absorber diameter. Chem. Eng. Sci. 71, 146$152(2012)$.

22. Rodriguez Castillo, A. S. et al. Synthesis and toxicity evaluation of hydrophobic ionic liquids for volatile organic compounds biodegradation in a two-phase partitioning bioreactor. J. Hazard. Mater. 307, 221-230 (2016).

23. Dumont, E. et al. VOC absorption in a countercurrent packed-bed column using water/silicone oil mixtures: Influence of silicone oil volume fraction. Chem. Eng. J. 168, $241-248(2011)$.

24. Quijano, G. et al. Absorption and Biodegradation of Hydrophobic Volatile Organic Compounds in Ionic Liquids. Water, Air, Soil Pollut. 224, 1528, $1-9$ (2013).

25. Nguyen, T. et al. Toluene degradation in a two-phase partitioning bioreactor involving a hydrophobic ionic liquid as a non-aqueous phase liquid. Int. Biodeterior. Biodegradation 117, 31-38 (2017).

26. Deng, Y. et al. Relevant parameters for assessing the environmental impact of some pyridinium, ammonium and pyrrolidinium based ionic liquids. Chemosphere 89, 327-33 (2012).

27. Zhang, C., Malhotra, S. V. \& Francis, A. J. J. Toxicity of imidazolium- and pyridiniumbased ionic liquids and the co-metabolic degradation of N-ethylpyridinium 
tetrafluoroborate. Chemosphere 82, 1690-5 (2011).

28. Burrell, A. K., Del Sesto, R. E., Baker, S. N., McCleskey, T. M. \& Baker, G. A. The large scale synthesis of pure imidazolium and pyrrolidinium ionic liquids. Green Chem. 9, 449454 (2007).

29. Corbera, R. et al. 'Cp* $\operatorname{Ir}(\mathrm{III})$ ' complexes with hemicleaveable ligands of the type Nalkenyl imidazolin-2-ylidene. reactivity and catalytic properties. Organometallics 26, 3492-3498 (2007).

30. González-Álvarez, J. et al. Polymeric imidazolium ionic liquids as valuable stationary phases in gas chromatography: chemical synthesis and full characterization. Anal. Chim. Acta 721, 173-81 (2012).

31. Wang, S.-W., Liu, W. \& Colby, R. H. Counterion Dynamics in Polyurethane-Carboxylate Ionomers with Ionic Liquid Counterions. Chem. Mater. 23, 1862-1873 (2011).

32. Fei, Z. et al. Revisiting ether-derivatized imidazolium-based ionic liquids. J. Phys. Chem. B 111, 10095-108 (2007).

33. Branco, L. C., Rosa, J. N., Moura Ramos, J. J. \& Afonso, C. A. M. Preparation and characterization of new room temperature ionic liquids. Chem. A Eurpean J. (Weinheim an der Bergstrasse, Ger. 8, 3671-7 (2002).

34. Carlisle, T. K., Bara, J. E., Gabriel, C. J., Noble, R. D. \& Gin, D. L. Interpretation of CO 2 Solubility and Selectivity in Nitrile-Functionalized Room-Temperature Ionic Liquids Using a Group Contribution Approach. Ind. Eng. Chem. Res. 47, 7005-7012 (2008).

35. Domańska, U. \& Zawadzki, M. Thermodynamic properties of the N-butylisoquinolinium bis(trifluoromethylsulfonyl)imide. J. Chem. Thermodyn. 43, 989-995 (2011). 
36. Daily, L. A. \& Miller, K. M. Correlating Structure with Thermal Properties for a Series of 1-Alkyl-4-methyl-1,2,4-triazolium Ionic Liquids. J. Org. Chem. 78, 4196-4201 (2013).

37. Zhao, D., Fei, Z., Ang, W. H. \& Dyson, P. J. Sulfonium-based Ionic Liquids Incorporating the Allyl Functionality. Int. J. Mol. Sci. 8, 304-315 (2007).

38. Larson, W. P., Cantwell, W. F. \& Hartzell, T. B. The Influence of the Surface Tension of the Culture Medium on the Growth of Bacteria. J. Natl. Dent. Assoc. 7, 205-208 (1920).

39. Laplace, P. S. Traité de mécanique céleste. (Paris, Duprat, 1799).

40. Ganapatibhotla, L. V. N. R., Zheng, J., Roy, D. \& Krishnan, S. PEGylated Imidazolium Ionic Liquid Electrolytes: Thermophysical and Electrochemical Properties. Chem. Mater. 22, 6347-6360 (2010).

41. Zhou, Z.-B., Matsumoto, H. \& Tatsumi, K. Low-melting, low-viscous, hydrophobic ionic liquids: 1-alkyl(alkyl ether)-3-methylimidazolium perfluoroalkyltrifluoroborate. Chem. A Eurpean J. (Weinheim an der Bergstrasse, Ger. 10, 6581-91 (2004).

42. Zhou, Z.-B., Matsumoto, H. \& Tatsumi, K. Low-melting, low-viscous, hydrophobic ionic liquids: aliphatic quaternary ammonium salts with perfluoroalkyltrifluoroborates. Chem. A Eurpean J. (Weinheim an der Bergstrasse, Ger. 11, 752-66 (2005).

43. Tang, S., Baker, G. A. \& Zhao, H. Ether- and alcohol-functionalized task-specific ionic liquids: attractive properties and applications. Chem. Soc. Rev. 41, 4030-66 (2012).

44. Jin, H. et al. Physical properties of ionic liquids consisting of the 1-butyl-3methylimidazolium cation with various anions and the bis(trifluoromethylsulfonyl)imide anion with various cations. J. Phys. Chem. B 112, 81-92 (2008).

45. Chen, Z. J., Xue, T. \& Lee, J.-M. What causes the low viscosity of ether-functionalized 
ionic liquids? Its dependence on the increase of free volume. $R S C A d v .2$, 10564-10574 (2012).

46. Zhang, S., Sun, N., He, X., Lu, X. \& Zhang, X. Physical Properties of Ionic Liquids: Database and Evaluation. J. Phys. Chem. Ref. Data 35, 1475 (2006).

47. Seddon, K. R., Stark, A. \& Torres, M.-J. Influence of chloride, water, and organic solvents on the physical properties of ionic liquids. Pure Appl. Chem. 72, 2275-2287 (2000).

48. Jacquemin, J., Husson, P., Padua, A. A. H. H. \& Majer, V. Density and viscosity of several pure and water-saturated ionic liquids. Green Chem. 8, 172-180 (2006).

49. Glasser, L. Lattice and phase transition thermodynamics of ionic liquids. Thermochim. Acta 421, 87-93 (2004).

50. Bittner, B., Wrobel, R. J. \& Milchert, E. Physical properties of pyridinium ionic liquids. $J$. Chem. Thermodyn. 55, 159-165 (2012).

51. Liu, Q. et al. Density and Surface Tension of Ionic Liquids [ C n py ][ NTf 2 ] ( n ) 2, 4, 5 ). J. Chem. Eng. Data 55, 4928-4930 (2010).

52. Liu, Q.-S., Li, P.-P., Welz-Biermann, U., Chen, J. \& Liu, X.-X. Density, dynamic viscosity, and electrical conductivity of pyridinium-based hydrophobic ionic liquids. $J$. Chem. Thermodyn. 66, 88-94 (2013).

53. Liu, Q.-G. et al. Physicochemical Properties of Ionic Liquids [C3py][NTf2] and. J. Chem. Eng. Data 56, 4094-4101 (2011).

54. Handbook of Chemistry and Physics.

55. Liu, Q.-S., Li, P.-P., Welz-Biermann, U., Chen, J. \& Liu, X.-X. Density, dynamic viscosity, and electrical conductivity of pyridinium-based hydrophobic ionic liquids. $J$. 
Chem. Thermodyn. 66, 88-94 (2013).

56. Fang, D.-W., Tong, J., Guan, W., Wang, H. \& Yang, J.-Z. Predicting properties of amino acid ionic liquid homologue of 1-alkyl-3-methylimidazolium glycine. J. Phys. Chem. B 114, 13808-14 (2010).

57. Fang, D.-W., Guan, W., Tong, J., Wang, Z.-W. \& Yang, J.-Z. Study on physicochemical properties of ionic liquids based on alanine $[\mathrm{Cnmim}][\mathrm{Ala}](\mathrm{N}=2,3,4,5,6)$. J. Phys. Chem. B 112, 7499-505 (2008).

58. Tong, J. et al. Prediction of the Physicochemical Properties of Valine Ionic Liquids [C n $\operatorname{mim}][\mathrm{Val}](\mathrm{n}=2,3,4,5,6)$ by Semiempirical Methods. Ind. Eng. Chem. Res. 50, 24182423 (2011).

59. Janz, G. J. Thermodynmic Properties of Organic Compounds. (Academic Press, 1967).

60. Widegren, J. A., Laesecke, A. \& Magee, J. W. The effect of dissolved water on the viscosities of hydrophobic room-temperature ionic liquids. Chem. Commun. (Camb). 1610-2 (2005). doi:10.1039/b417348a

61. Seddon, K. R., Stark, A. \& Torres, M. M. Viscosity and Density of 1-Alkyl-3methylimidazolium Ionic Liquids. ACS Symp. Ser. 819, 34-49 (2002).

62. Gomes de Azevedo, R. et al. Thermophysical and thermodynamic properties of ionic liquids over an extended pressure range: [bmim][NTf2] and [hmim][NTf2]. J. Chem. Thermodyn. 37, 888-899 (2005).

63. Rodríguez, H. \& Brennecke, J. F. Temperature and Composition Dependence of the Density and Viscosity of Binary Mixtures of Water + Ionic Liquid. J. Chem. Eng. Data 51, 2145-2155 (2006). 
64. Yoshida, Y., Baba, O. \& Saito, G. Ionic liquids based on dicyanamide anion: Influence of structural variations in cationic structures on ionic conductivity. J. Phys. Chem. B 111, 4742-4749 (2007).

65. Fuller, J. The Room Temperature Ionic Liquid 1-Ethyl-3-methylimidazolium Tetrafluoroborate: Electrochemical Couples and Physical Properties. J. Electrochem. Soc. 144, 3881 (1997).

66. Noda, A., Hayamizu, K. \& Watanabe, M. Pulsed-Gradient Spin-Echo 1 H and 19 F NMR Ionic Diffusion Coefficient, Viscosity, and Ionic Conductivity of Non-Chloroaluminate Room-Temperature Ionic Liquids. J. Phys. Chem. B 105, 4603-4610 (2001).

67. Bonhôte, P. et al. Hydrophobic, Highly Conductive Ambient-Temperature Molten Salts. Inorg. Chem. 35, 1168-1178 (1996).

68. Suarez, P. A. Z., Einloft, S., Dullius, J. E. L., de Souza, R. F. \& Dupont, J. Synthesis and physical-chemical properties of ionic liquids based on 1-n-butyl-3-methylimidazolium cation. J. Chim. Phys. Physico-Chimie Biol. 95, 1626-1639 (1998).

69. Yu, G., Zhao, D., Wen, L., Yang, S. \& Chen, X. Viscosity of Ionic Liquids : Database , Observation, and Quantitative Structure-Property Relationship Analysis. AIChE J. 58, 2885-2899 (2012).

70. Seki, S. et al. Effects of cation and anion on physical properties of room-temperature ionic liquids. J. Mol. Liq. 152, 9-13 (2010).

71. Zhou, Z.-B., Matsumoto, H. \& Tatsumi, K. Cyclic quaternary ammonium ionic liquids with perfluoroalkyltrifluoroborates: synthesis, characterization, and properties. Chem. A Eurpean J. (Weinheim an der Bergstrasse, Ger. 12, 2196-212 (2006). 
72. Tsunashima, K. \& Sugiya, M. Physical and electrochemical properties of low-viscosity phosphonium ionic liquids as potential electrolytes. Electrochem. commun. 9, 2353-2358 (2007).

73. Le, M. L. P. et al. Structure-properties relationships of lithium electrolytes based on ionic liquid. J. Phys. Chem. B 114, 894-903 (2010).

74. Huddleston, J. G. et al. Characterization and comparison of hydrophilic and hydrophobic room temperature ionic liquids incorporating the imidazolium cation. Green Chem. 3, $156-164(2001)$.

75. Kolbeck, C. et al. Density and surface tension of ionic liquids. J. Phys. Chem. B 114, $17025-36(2010)$.

76. Kilaru, P., Baker, G. A. \& Scovazzo, P. Density and surface tension measurements of imidazolium-, quaternary phosphonium-, and ammonium-based room-temperature ionic liquids: Data and correlations. J. Chem. Eng. Data 52, 2306-2314 (2007).

77. Rusanov, A. I. \& Prokhorov, V. A. Interfacial Tensiometry. Studies in Interface Science 3, (Elsevier, 1996).

78. Vazquez, G., Alvarez, E. \& Navaza, J. M. Surface Tension of Alcohol Water + Water from 20 to 50 .degree.C. J. Chem. Eng. Data 40, 611-614 (1995).

79. Součková, M., Klomfar, J. \& Pátek, J. Surface tension and $0.1 \mathrm{MPa}$ densities of imidazolium-, $\quad$ pyridinium-, $\quad$ pyrrolidinium-, $\quad$ and piperidinium-based tris(pentafluoroethyl)trifluorophosphate ionic liquids. Fluid Phase Equilib. 333, 38-46 (2012).

80. Freire, M. G. et al. Surface tensions of imidazolium based ionic liquids: Anion, cation, 
temperature and water effect. J. Colloid Interface Sci. 314, 621-630 (2007).

81. Dzyuba, S. V. \& Bartsch, R. A. Influence of Structural Variations in Hexafluorophosphates and Bis ( trifluoromethyl- sulfonyl ) imides on Physical Properties of the Ionic Liquids **. Chemphyschem a Eur. J. Chem. Phys. Phys. Chem. 3, 161-166 (2002).

82. Adamson, A. W. \& Gast, A. P. Physical Chemistry of Surfaces Sixth Edition. SubStance 124, 192C (1997).

83. Korosi, G. \& Kovats, E. S. Density and surface tension of 83 organic liquids. J. Chem. Eng. Data 26, 323-332 (1981).

84. Law, G. \& Watson, P. R. Surface Tension Measurements of N -Alkylimidazolium Ionic Liquids. Langmuir 17, 6138-6141 (2001).

85. Law, G. \& Watson, P. R. Surface orientation in ionic liquids. Chem. Phys. Lett. 345, 1-4 (2001). 


\section{Tables}

Table 1 Chemical structures of the studied Ionic Liquids

\begin{tabular}{|c|c|c|}
\hline Ionic liquid & Abbreviation & Chemical structure \\
\hline $\begin{array}{l}\text { 3-Butyl-1-methylimidazolium } \\
\text { bis(trifluoroethylsulfonyl)imide }\end{array}$ & {$[\mathrm{Bmim}]\left[\mathrm{NTf}_{2}\right]$} & \\
\hline $\begin{array}{l}\text { 3-Butyl-1-methylimidazolium } \\
\text { hexafluorophosphate }\end{array}$ & {$[\mathrm{Bmim}]\left[\mathrm{PF}_{6}\right]$} & \\
\hline $\begin{array}{l}\text { 1-Butyl-3-methylimidazolium } \\
\text { nonafluorobutylsulfonate }\end{array}$ & {$[\mathrm{Bmim}][\mathrm{NfO}]$} & \\
\hline $\begin{array}{l}\text { 3-Propyl-1-methylimidazolium } \\
\text { bis(trifluoromethylsulfonyl)imide }\end{array}$ & {$[\mathrm{nPrmim}]\left[\mathrm{NTf}_{2}\right]$} & \\
\hline $\begin{array}{l}\text { 3-Isopentyl-1-methylimidazolium } \\
\text { hexafluorophosphate }\end{array}$ & {$[\mathrm{iPentmim}]\left[\mathrm{PF}_{6}\right]$} & \\
\hline $\begin{array}{l}\text { 3-Isopentyl-1-methylimidazolium } \\
\text { bis(trifluoromethylsulfonyl)imide }\end{array}$ & {$[\mathrm{iPentmim}]\left[\mathrm{NTf}_{2}\right]$} & \\
\hline $\begin{array}{l}\text { 3-Butenyl-1-methylimidazolium } \\
\text { hexafluorophosphate }\end{array}$ & {$[$ Butenylmim $]\left[\mathrm{PF}_{6}\right]$} & \\
\hline $\begin{array}{l}\text { 3-Butenyl-1-methylimidazolium } \\
\text { bis(trifluoromethylsulfonyl)imide }\end{array}$ & [Butenylmim] $\left[\mathrm{NTf}_{2}\right]$ & \\
\hline $\begin{array}{l}\text { 3-Butenyl-1-methylimidazolium } \\
\text { nonafluorobutylsulfonate }\end{array}$ & [Butenylmim][NfO] & \\
\hline $\begin{array}{l}\text { 3-(1-methoxyethyl)-1- } \\
\text { methylimidazolium } \\
\text { bis(trifluoromethylsulfonyl)imide }\end{array}$ & {$[\mathrm{MeOEmim}]\left[\mathrm{NTf}_{2}\right]$} & \\
\hline $\begin{array}{c}\text { 3-(1-ethoxyethyl)-1- } \\
\text { methylimidazolium } \\
\text { bis(trifluoromethylsulfonyl)imide } \\
\text { 3-(1-methoxyethoxyethyl)-1- } \\
\text { methylimidazolium } \\
\text { bis(trifluoromethylsulfonyl)imide } \\
<\text { sup }>32,33</ \text { sup }><\text { sup }>32,33</ \text { s } \\
\text { up }><\text { sup }>32,33</ \text { sup }>\end{array}$ & {$[\mathrm{MeOEOEmim}]\left[\mathrm{NTf}_{2}\right]$} & \\
\hline $\begin{array}{l}\text { 1-octylisoquinolinium } \\
\text { bis(trifluoromethylsulfonyl)imide }\end{array}$ & {$[\mathrm{OctIq}]\left[\mathrm{NTf}_{2}\right]$} & \\
\hline
\end{tabular}


1-(-1-methoxyethyl)isoquinolinium

bis(trifluoromethylsulfonyl)imide

1-(-1-methoxyethyl)isoquinolinium

bis(trifluoromethylsulfonyl)imide

1-(-1- ethoxyethyl)isoquinolinium

bis(trifluoromethylsulfonyl)imide

3-(4-butyronitrile)-1methylimidazolium

bis(trifluoromethylsulfonyl)imide 1-butyl-3-methyl-1H$[1,2,4]$ triazolium

bis(trifluoromethylsulfonyl)imide

1-butyl-3-(1,1,2-trifluoro-1butenyl)-1H-[1,2,4]triazolium bis(trifluoromethylsulfonyl)imide

1-Butyl-1-methylpyrrolidinium bis(trifluoromethylsulfonyl)imide

Allyl-diethylsulfonium bis(trifluoromethylsulfonyl)imide

4-Methoxyethyl-4methylmorpholinium bis(trifluoromethylsulfonyl)imide 4-Ethoxyethyl-4methylmorpholinium bis(trifluoromethylsulfonyl)imide
[DecIq][NTf $\left.\mathrm{N}_{2}\right]$

$[\mathrm{MeOEIq}]\left[\mathrm{NTf}_{2}\right]$

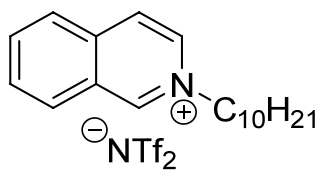<smiles>COCC[n+]1ccc2ccccc2c1</smiles>

[EtOEIq][NTf $\left.{ }_{2}\right]$<smiles>CCOC[n+]1ccc2ccccc2c1</smiles>

$\left[\mathrm{CNC}_{3} \operatorname{mim}\right]\left[\mathrm{NTf}_{2}\right]$

$[\mathrm{BMTriaz}]\left[\mathrm{NTf}_{2}\right]$<smiles></smiles><smiles>CCCCn1c[n+](C)cn1</smiles>

$\left[\mathrm{CF}_{3} \mathrm{CF}_{2} \mathrm{BTriaz}\right]\left[\mathrm{NTf}_{2}\right]$

[BMPyrr][NTf $\left.{ }_{2}\right]$<smiles></smiles>

[AllylEt $\left.{ }_{2} \mathrm{~S}\right]\left[\mathrm{NTf}_{2}\right]$<smiles>CCCC[N+]1(C)CCCC1</smiles>

[MeOEMMorph][NTf $\left.{ }_{2}\right]$<smiles>C=CC[SiH](CC)CC</smiles><smiles>COCC[N+]1(C)CCOCC1</smiles>

[EtOEMMorph][ $\left.\mathrm{NTf}_{2}\right]$

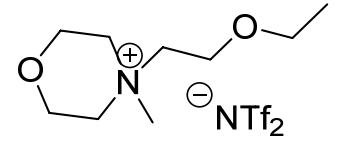


Table 3. Viscosity $\mu$ (mPa s) measurements at different temperatures. Experimental uncertainties do not exceed $2.0 \%$.

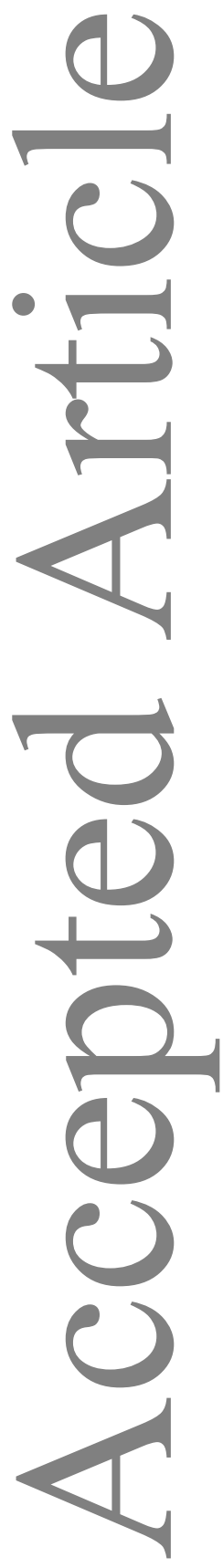

\begin{tabular}{|c|c|c|c|c|c|}
\hline \multirow[b]{2}{*}{ IL } & \multicolumn{5}{|c|}{$T / \mathrm{K}$} \\
\hline & 293.15 & 295.65 & 298.15 & 300.65 & 303.15 \\
\hline$[\mathrm{Bmim}]\left[\mathrm{NTf}_{2}\right]$ & 58.7 & 53.1 & 47.7 & 43.1 & 39.2 \\
\hline$[\mathrm{Bmim}]\left[\mathrm{PF}_{6}\right]$ & 230.1 & 205.0 & 183.3 & 165.0 & 148.5 \\
\hline$[\mathrm{Bmim}][\mathrm{NfO}]$ & 311.0 & 277.7 & 232.3 & 204.0 & 176.7 \\
\hline$[\mathrm{nPrmim}]\left[\mathrm{NTf}_{2}\right]$ & 61.4 & 54.9 & 49.6 & 44.5 & 43.6 \\
\hline$[\mathrm{iPentmim}]\left[\mathrm{PF}_{6}\right]$ & 504.5 & 434.1 & 373.9 & 332.2 & 282.4 \\
\hline$\left[\right.$ iPentmim] $\left[\mathrm{NTf}_{2}\right]$ & 80.4 & 70.5 & 63.2 & 56.6 & 50.7 \\
\hline [Butenylmim] $\left[\mathrm{PF}_{6}\right]$ & 189.9 & 173.1 & 153.3 & 139.0 & 125.9 \\
\hline [Butenylmim] $\left[\mathrm{NTf}_{2}\right]$ & 63.5 & 56.5 & 51.2 & 46.2 & 41.4 \\
\hline [Butenylmim][NfO] & 331.7 & 285.3 & 240.7 & 208.4 & 178.1 \\
\hline$[\mathrm{MeOEmim}]\left[\mathrm{NTf}_{2}\right]$ & 63.9 & 57.8 & 53.0 & 49.0 & 44.9 \\
\hline$[$ EtOEmim $]\left[\mathrm{NTf}_{2}\right]$ & 46.9 & 42.1 & 38.7 & 35.4 & 32.6 \\
\hline$[\mathrm{MeOEOEmim}]\left[\mathrm{NTf}_{2}\right]$ & 65.3 & 58.3 & 53.7 & 48.8 & 44.7 \\
\hline$[\mathrm{MeOEmim}][\mathrm{NfO}]$ & 373.0 & 315.1 & 268.5 & 227.4 & 192.1 \\
\hline$[\mathrm{OctIq}]\left[\mathrm{NTf}_{2}\right]$ & 620.6 & 527.0 & 451.0 & 392.3 & 331.9 \\
\hline$[\mathrm{DecIq}]\left[\mathrm{NTf}_{2}\right]$ & 667.0 & 554.2 & 464.1 & 392.6 & 333.0 \\
\hline$[\mathrm{MeOEIq}]\left[\mathrm{NTf}_{2}\right]$ & 441.4 & 375.5 & 318.6 & 269.5 & 228.9 \\
\hline$[\mathrm{EtOEIq}]\left[\mathrm{NTf}_{2}\right]$ & 443.4 & 374.0 & 309.6 & 260.9 & 221.4 \\
\hline$\left[\mathrm{CNC}_{3} \mathrm{mim}\right]\left[\mathrm{NTf}_{2}\right]$ & 274.6 & 239.9 & 210.5 & 185.3 & 164.8 \\
\hline$[\mathrm{BMTriaz}]\left[\mathrm{NTf}_{2}\right]$ & 106.1 & 93.4 & 84.3 & 75.7 & 66.7 \\
\hline$\left[\mathrm{CF}_{3} \mathrm{CF}_{2} \mathrm{BTriaz}\right]\left[\mathrm{NTf}_{2}\right]$ & 102.9 & 90.8 & 81.8 & 73.3 & 66.6 \\
\hline$[\mathrm{BMPyrr}]\left[\mathrm{NTf}_{2}\right]$ & 102.9 & 90.8 & 81.8 & 73.3 & 66.6 \\
\hline [AllylEt2S][NTf 2$]$ & 50.9 & 45.7 & 41.7 & 38.1 & 35.2 \\
\hline$[\mathrm{MeOEMMorph}]\left[\mathrm{NTf}_{2}\right]$ & 469.2 & 388.6 & 332.8 & 282.0 & 231.6 \\
\hline [EtOEMMorph][ $\left.\mathrm{NTf}_{2}\right]$ & 375.0 & 315.5 & 268.5 & 229.0 & 197.4 \\
\hline
\end{tabular}


Table 4. Experimental surface tension (in $\mathrm{mN} \mathrm{m}^{-1}$ ) for all ILs at different temperature and at atmospheric pressure. The experimental uncertainties do not exceed $2.0 \%$

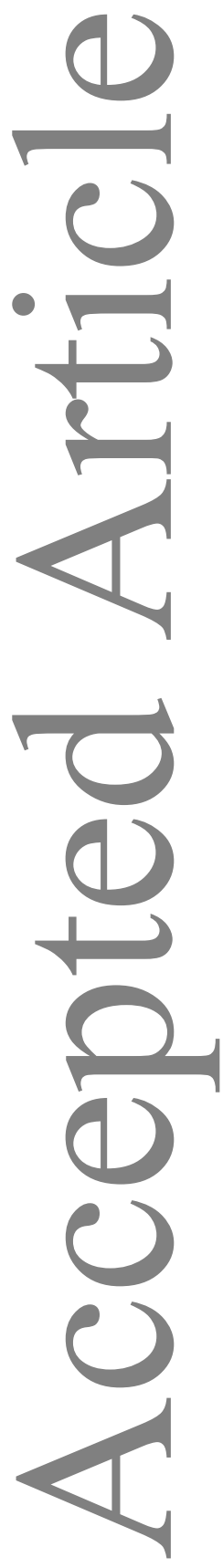

\begin{tabular}{|c|c|c|c|c|}
\hline & \multicolumn{4}{|c|}{$T / \mathrm{K}$} \\
\hline $\mathrm{IL}$ & 88.15 & 298.15 & 308.15 & 318.15 \\
\hline$\overline{[\mathrm{Bmim}]\left[\mathrm{NTf}_{2}\right]}$ & 32.71 & 2.49 & 32.29 & 32.08 \\
\hline$[\mathrm{Bmim}]\left[\mathrm{PF}_{6}\right]$ & 42.35 & .51 & 40.89 & 0.16 \\
\hline$[\mathrm{Bmim}][\mathrm{NfO}]$ & 22.00 & 21.58 & 21.17 & 20.72 \\
\hline$[\mathrm{nPrmim}]\left[\mathrm{NTf}_{2}\right]$ & 32.96 & 32.41 & 32.03 & 31.82 \\
\hline$[$ iPentmim$]\left[\mathrm{PF}_{6}\right]$ & 38.36 & 37.90 & 37.39 & 37.07 \\
\hline$[$ iPentmim $]\left[\mathrm{NTf}_{2}\right]$ & 31.00 & 30.65 & 30.21 & 29.70 \\
\hline [Butenylmim] $]\left[\mathrm{PF}_{6}\right]$ & 34.22 & 34.02 & 33.88 & 33.80 \\
\hline$\left[\right.$ Butenylmim] $\left[\mathrm{NTf}_{2}\right]$ & 34.13 & 33.68 & 33.23 & 33.08 \\
\hline [Butenylmim] [NfO] & 23.97 & 23.18 & 22.90 & 22.65 \\
\hline$[\mathrm{MeOEmim}]\left[\mathrm{NTf}_{2}\right]$ & 36.12 & 35.57 & 34.97 & 34.31 \\
\hline$[$ EtOEmim $]\left[\mathrm{NTf}_{2}\right]$ & 33.22 & 32.76 & 32.29 & 31.71 \\
\hline$[\mathrm{MeOEOEmim}]\left[\mathrm{NTf}_{2}\right]$ & 36.16 & 35.42 & 34.72 & 34.03 \\
\hline [OctIq] $\left[\mathrm{NTf}_{2}\right]$ & 31.85 & 30.48 & 29.98 & 29.13 \\
\hline$[\mathrm{DecIq}]\left[\mathrm{NTf}_{2}\right]$ & 29.30 & 28.88 & 28.53 & 28.14 \\
\hline$[\mathrm{MeOEIq}]\left[\mathrm{NTf}_{2}\right]$ & 36.95 & 36.45 & 35.61 & 34.52 \\
\hline$\left[\right.$ EtOEIq] $\left[\mathrm{NTf}_{2}\right]$ & 35.56 & 35.14 & 34.61 & 34.17 \\
\hline$\left[\mathrm{CNC}_{3} \mathrm{mim}\right]\left[\mathrm{NTf}_{2}\right]$ & 40.58 & 40.05 & 39.42 & 38.44 \\
\hline$[\mathrm{BMTriaz}]\left[\mathrm{NTf}_{2}\right]$ & 31.14 & 30.61 & 30.12 & 29.59 \\
\hline$\left[\mathrm{CF}_{3} \mathrm{CF}_{2} \mathrm{BTriaz}\right]\left[\mathrm{NTf}_{2}\right]$ & 28.42 & 28.04 & 27.71 & 27.29 \\
\hline$[\mathrm{BMPyrr}]\left[\mathrm{NTf}_{2}\right]$ & 33.23 & 32.79 & 32.34 & 31.82 \\
\hline$\left[\right.$ AllylEt $\left._{2} \mathrm{~S}\right]\left[\mathrm{NTf}_{2}\right]$ & 32.37 & 31.97 & 31.62 & 31.13 \\
\hline [MeOEMMorph] $\left[\mathrm{NTf}_{2}\right]$ & 36.52 & 35.83 & 35.33 & 34.70 \\
\hline$\left[\right.$ EtOEMMorph] $\left[\mathrm{NTf}_{2}\right]$ & 34.01 & 33.62 & 33.06 & 32.31 \\
\hline
\end{tabular}

